INTERNATIONAL JOURNAL OF RESEARCHES IN BIOSCIENCES, AGRICULTURE AND TECHNOLOGY (C) VISHWASHANTI MULTIPURPOSE SOCIETY (Global Peace Multipurpose Society) R. No. MH-659/13(N) www.ijrbat.in

\title{
AVIFAUNAL DIVERSITY IN AND AROUND TAHSILPOMBHURNA OF DIST. CHANDRAPUR (M.S.) INDIA
}

\author{
Deshpande A. S.* \\ *Deptt.t of Zoology, Chintamani College of Science, Pombhurna, Dist.Chandrapur(M.S.) India \\ anant@chintamani.edu.in
}

\begin{abstract}
:
Pombhurna is a tahsil place located in district Chandrapur of Maharashtra State, India. Pombhurna is covered with dense forest in and around and having rich faunal diversity spread in its vicinity. It harbors several kinds of birds in most of rainy and winter season as grassland area, rice fields, herbs, shrubs and various trees located in the vicinity provides essential required food and shelter to these birds. As the area is free from all anthropological activities, the environment is most suitable for the fauna to sustain without any disturbance. About 62 different birds were recorded in the present study report. The details of reported avifaunal diversity were reported in the given study.
\end{abstract}

Keywords: Avifauna, biodiversity, forest, Pombhurna

\section{INTRODUCTION:}

It is very essential to monitor the bird diversity in any divine natural habitat, ecological area so as to observe their ability to respond on various environmental factors like disturbances, damage created for human development against the destruction of natural habitat. The quality of any natural habitat or environment is reflected by presence or disappearance of any avifaunal animals in there vicinity, which may reflect the impact of development on their habitat. Birds are always amazing to all due to their long and constant journey to overcome the unfavorable conditions and to find and reach the suitable feeding and breeding grounds. Birds are always fighting against the environmental factors since long time and adapted themselves against environmental as well as anthropological disturbances in the recent years is something remarkable. As compare to all other habitats, like water bodies with vegetation, hydrophytes and surrounding scrub, tree cover was most suitable for congregating diversity of bird species (Newton, 1995; Islam and Rahmani, 2004). Water bodies also support wide range of biodiversity hence most suitable for birds to get variety of food, good and safe shelter to lay the eggs (Islam and Rahmani, 2004).
It is being suggested that avifauna are important for the ecosystem as they play various roles as a Scavenger, Pollinatorand predators of insect pest (Padmavati et al., 2010). The developmental projects, Industrialization, Urbanization disturbs avian fauna (Bhattacharjee and Hazarika; Sharma and Saini, 1985).

There are more than about thousands species of birds in the world. India harbors 1318 species of which 57 are endemic, 03 breeding endemicand 85 species are threatened (Bird life International, 2014). AVIBASE (2015)reported the existence of 616 species of birds in Maharashtra State of which 33 are threatened and 01 is introduced species (Birdlife International, 2010).

Pombhurna tahsil is surrounded by Multahsil on one side and by Ballarpur and Chandrapur city on other. It is placed between known Mul and Ballarpur tahsil and shows dense forest coving various trees specially bamboo. The studied area is well nourished and shows feasible nutrition in rainy and winter season but during spring and summer the water level drops its maximum and the small and large plants are unable to get there water requirement and nutrition too.

In the rainy season due to availability of sufficient water shrubs and other small plants, trees can 
easily grow at the maturity and are naturally available shelter for the resident/migrating birds. The flooded water contains small phytoplankton, insect larvae, worms and small plants which serve as food for various resident and migrating birds. In the winter season as the rice fields are at their flowering stage the paddy areas also serve as shelter during winter with fresh food and nutrition for birds. The paddy and flowering rice field attracts the most of migrating birds so the season sighted diverse bird counting.

\section{METHOD AND MATERIAL:}

The present work was carried out from July 2016 to July 2017. The observation were carried out by using a field binocular (7X25X magnification) during the morning ( 6 to $10 \mathrm{AM}$ ) and in the evening (4 to 7 PM) and identification of species was done with the help of standard literature of Woodcock (1980), Ali, S. and Ripley, S.D. (1995) and Grimmet et al., (1999).

\section{RESULT AND DISCUSSION:}

During the present investigation, a total of 62 birds belonging to 15 different orders and 40families were recorded from the study area. Among the recorded species of birds, 22 species belongs to Passeriformes, 8 species belongs to Charadriformes, 8 species belongs to Ciconiformes, 6species belongs to Coraciformes, 4 species belongs to Psittaciformes, Columbiformes, 2 from Galliformes, one species belongs to Anciriformes, Podicipediformes, Passeridae, Pelecaniformes, Apodiformes, Cuculiformes, Piciformeseach and 2 species from Pelecaniformes.

Among the recorded species of birds 7 species belongs to Scolopacidae families, 5 species belongs toColumbidae, 4 species belongs to Ardeidae and Sturnidae families and 5 from Muscicapidae, 2 from Passeridae and Phalcrocoracidae familly single species belongs to Gruidae, Corvidae, Ciconidae, Anatidae, Psittacidae, Cuculidae, Alcedinidae, Muscicapidae, Meropidae, Coraciidae, Upupidae,
Alcedinidae, Lanidae, Dicrudidae, Hirudinidae, Laniidae, Sylvidae, Campephagidae,, Passeridae, Motacillidae, Estrildidae, Picidae, Cuculidae, Apodiae, Podicipedidae, Threskiornithidae, Scolopacidae, Pycnonotidae, Phasinidae, Phalcrocoracidae, and Charadridae families each. Out of total 62 species, 53 were resident, 08 were resident migrant and 1 is resident migrant common. Similar findings were recorded as 95 species of birds were recorded of 13 different orders and 37 families during the study by Harney (2015) in Mohurly area of Chandrapur District, Osmaston (1922) studied 135 species of birds from Pachmari (M.P.), Ali (1939, 1940) published a list of 278 species of birds from central India, Mujumdar (1984) studied the collection from Baster district (M.P.), Newton et al., (1986) have listed the birds of Kanha Tiger Reserve (M.P.), Ghosal (1995) have listed the birds of Kanha Tiger Reserve (M.P.), Wadatkar and Kasambe (2002) reported 171 species of birds at Pohara-Malkhed forest reservoir of Amravati district( M.S.), Yardi et al., (2004) reported 64 species of birds in Salim Ali lake, Aurangabad (M.S.), Kedar and Patil (2005) recorded 60 birds species from Rishi lake Karanja (Lad) of Washim district(M.S.), Pawar et al.,(2005) reported 74 species of birds in and around Yedshi lake, Mangrulpir, Washim district (M.S.), Kulkarni et al., (2005) reported 151 species of birds in and around Nanded city (M.S.), Kulkarni and Kanwate (2006) reported 18 species of birds in Dongarkhed irrigation of Hingoli district. (M.S.), Kulkarni et al., (2006) reported 93 species of birds from Shikhachwadi reservoir of Nanded district (M.S.), Kedar et al., (2008) recorded 74 species of birds in Rishi and Zedshi lake of Washim district (M.S.), Kanwate and Jadhao (2010) recorded 10 species of birds inBhokartahsil of Nanded district (M.S.), Kulkarni and Kanwate (2010) reported 62 species of birds ofJaldhara forest of Kinwat of Nanded district(M.S.), Thakor et al., (2010) reported 104 species of birds from two reservoirs of Khed district, Gujrat, India. Kurhade (2010) reported 208 species 
of birds inJaikwadi reservoirs near Ahmadnagar (M.S.), Narwade and Fartade (2011) recorded 165 species ofbirds of Osmanabad district (M.S.), Rasal and Chavan (2011) reported 61 species of birds in local ecosystem of Aurangabad(M.S.), Kukade et al., (2011) recorded 68 birds species of Chhatri lake of Amravati district(M.S.), Harney, et al., (2012) recorded 37 species of birds from Kanhala pond of Bhadrawati, District Chandrapur (M.S.), Joshi and K. Shrivastava (2012) reported 64 species of birdsinTawa reservoir of Hoshangabad district(M.P.), Hippargi et al., (2012) recorded 65 species of birds in a highly fragmented grassland patch near Solapur, Maharashtra and Patel et al.,(2012) recorded 70species of birds of Mahi canal site of Nadiad (Gujrat state), Harney, et al., (2013) recorded 37 species of birds from Kanhala pond with preference to feeding habits of Bhadrawati, District Chandrapur (M.S.) and Natarajan Mariappan et al., (2013) recorded 92 species of birds from Different Habitatsof Agricultural Ecosystem of Pollachi (T.N.)

\section{CONCLUSION:}

From the present study it can be concluded that Pombhurna region is preferred by variety of migrating and resident birds during their journey as the rainy and winter season satisfy their essential requirement to survive in this region for feeding and breeding purpose.

\section{REFERANCE :}

Ali S. (1932): Flowers birds and birds flower in India. J. Bom. Nat. Hist. Soc. 35, 573-605.

Ali S. (1939): The birds of central India, Part-1. J. Bom. Nat. Hist. Soc. 41(1) 82-106.

Ali, S. and Ripley, S.D. (1995): A pictorial guide to the birds of the Indian subcontinent. Bombay Natural history society, Mumbai.

Avibase (2015): The World Bird Database. (www.avibase.org).

Bhattacharjee P.C. and Hazarika B.C., (1985): Roosting sites and roosting birds at GauhatiMuncipal area, Second International symposium on life sciences., NEHU Shillong.

Birdlife International (2010): IUCN Rd List for birds. (http:// www.birdlife.org ).
Birdlife International.Undated Global IBA Criteria. (www. Birdlife.org / datazone / info / ibiacritglob).

Chilke A. M. (2012): Avian diversity in and around Bamanwadalake of Rajura, District Chandrapur (Maharashtra), Scholars Res. Libr 3(4), 2014-2018.

Dubey A. K. (2014): Bird diversity at Chhatarpur District Madhya Pradesh, India. Int. J. Glob. Sci. Res. 1(1) 25-32.

Ghazi H. K. (1962): Piscivorous birds of Madras, Madras. J. of fisheries. Vol. 1(1):106-107.

Ghosal D. N. (1995): Avifauna of conservation areas, No. 7, Fauna of Kanha Tiger Reserve. Zoological survey of India (ZSI), pp.63-91.

Grimmet, Richard; Inskipp, Carol and Inskipp, Tim (1999): A pocket guide to the birds of the Indian subcontinent. Oxford University Press, Mumbai.

Harney N. V. (2015): Avifaunal diversity of moharli lake near Chandrapur, Maharastra, India. International Journal of Global Science Research ISSN: 2348-8344 (Online) Vol.2 (4), October 2015, pp. 255-264

Harney N. V., Dhamani A. A. and Andrew R. J. (2013): Avifaunal diversity of Kanhalalake near Bhadrawati, Dist-Chandrapur (MS), with reference to food preference and feeding habits. India. ISRJ Special Issue.57-59.

Hippargi R. V., Bolde P. M. Manthen S. V. Aland S.R. (2012): Population and breeding status of avifauna in a highly fragmented grassland patch near Solapur, Maharashtra. AvishkarSolapur University Research Journal, 2, 22-30.

Islam Z. U., Rahmani A. R. (2004): Important Bird areas in India, Priority sites for conservation Network: Bombay Natural History Society and Bird Life International (UK).

Jhingran V. G. (1988) Fish an fisheries of India. Hindustan Publishing cooperation, New Delhi.pp.1-664.

Joshi P. and Shrivastava V. K. (2012): Avifaunal diversity of Tawa reservoir and its surrounding area of Hoshangabad district (M.P.). Inter. J. Plant, Animal Environ. Sci. 2(1), 46-51. 
Kannan P. (1980): Nector feeding adaptation of flower birds. J. Bom. Nat. Hist. Soc. 75 (Suppl.) 1036-1050.

Kanwate V. S. and Jadhao V. S. (2010): Piscivorous birds of Dhanora tank in Bhokartahsil of Nanded district, Maharashtra. J.of Ecology and fisheries. 3(1), 27-30.

Kedar G. T. and Patil G. P. (2005): Avifaunal diversity of Rishi lake, Karanja (Lad), Maharashtra with reference to food preference and feeding habits. J. Aqua. Biol. 20(1), 35-38.

Kedar G. T., Patil G. P. and Yeole S. M. (2008): Comparative study of a avifaunal status of two freshwater lakes of Washim district, Maharashtra. J. Aqua. Biol. 23(1), 29-33.

Kulkarni A. N. and Kanwate V. S. (2006): Avifauna of forest Jaldhara, Kinwat, District Nanded, Maharashtra, J. Aqua. Biol. 21(1), 46-51.

Kulkarni A. N. and Kanwate V. S. (2006): Piscivorous birds of Dongarkheda irrigation tank, Dist. Hingoli, Maharashtra, J. Aqua. Biol. 21(1), 86-87.

Kulkarni A. N., Kanwate V. S. and Deshpande V. D. (2005): Birds in and around Nanded city, Maharashtra. Zoo's print journal. 20(11), 20762078.

Kurhade S. (2010): Status and Diversity of avifauna in Jaikwadi reservoirs, Maharashtra. J. Aqua. Biol. 25(1), 32-40.

Mujumdar N. (1984): On a collection of birds from Bastar district, M.P. Record Zoological survey of India, Occasional paper No.59, 54.

Narwade S. and Fartade M. M. (2011): Birds of Osmanabad district of Maharashtra, India. Journal of Thretened Taxa. 3(2),1567-1576.

NatarajanMariappan

B. $\mathrm{K}$. AhamedKalfanSrinivasagamKrishnakumar (2013): Assessment of Bird Population in Different Habitats of Agricultural Ecosystem. JSRES, 1(11), 306-316.

Newton P. N., Brudin S. and Guy J. (1986): The birds of Kanha Tiger Reserve Madhya Pradesh, India. J. Bom. Nat. Hist. Society. 83(3), $977-$ 998.

Osmaston B. B. (1922): A Birds OfPachmari. J. Bom. Nat. Hist. Soc. 28: 453- 459.Singh T. C.
N. (1929) A note of the pollination of ErythringIndica by birds. J. Bom. Nat. Hist. Soc. 33, 960-462.

Padmavati A., Alexandar R. and Anbarashan M., (2010): Our Nature, 8, 247-253.

Patel K. B., Patel S. B. and Nikunj B. (2012): Avian diversity of mahi canal site of Nadiad, Gujrat. Life Science Leaflets. 4, 12-19.

Pawar R. H., Patil G. P., Kedar G. T. and Yeole S.M. (2005): Diversity of avifauna in and around Yedshi lake, Mangrulpirtaluka, washim District, Maharashtra, India. Biodiversity of Lonar creator, Anamaya Publishers, New Delhi, India.PP.106-113.

Rasal G. B. and Chavan B. L. (2011): Diversity of birds in local ecosystem Aurangabad, Maharashtra, India. Journal of Economic and Sustainable Development (Online).

Sharma K.K. and SainiMinakshi, (2014): Community Structure and Population Dynamics of Aquatic Avifauna of Gharana Wetland (Reserve), Jammu, India, International Research Journal of Biological Sciences, 3(2), $1-8$.

Thakor F. J., Achrya C. A., Bhoi D. K., Prajapati J. R. and Vaidya J. S. (2010): A comparative study of avifauna from two reservoirs in Khed District, Gujrat, India. J. Aqua. Biol. 25(1), 41 45.

Wadatkar J. S. and Kasambe R. (2002): Checklist of Birds from Pohara-Malkhed reserve forest, Distt. Amravati, Maharashtra. Zoos.Print Journal. 17(66), 807-811.

Woodcock M. (1980): Collins Handguide to the Birds of Indian subcontinent. 2nd Edn. Collins, London. 
Table 1 Birds species observed in and around study area Pombhurna, District Chandrapur, Maharshtra State, India

\begin{tabular}{|c|c|c|c|c|}
\hline Sr. No. & Order/Family & Scientific name & Common name & Habit \\
\hline 1. & AnciriformesAnatidae & Anaspoecilorhyncha & Spot Bill Duck & RM \\
\hline 2. & ApodiformesApodiae & Apusaffinis & House swift & $\mathrm{R}$ \\
\hline 3. & CharadriformesCharadridae & Vanellusindicus & Red wattled Lapwing & $\mathrm{R}$ \\
\hline 4. & CharadriformesScolopacidae & Actitishypoleucos & Common Sandpiper & RM \\
\hline 5. & CharadriformesScolopacidae & Tringanebularia & Common Greenshank & $\mathrm{R}$ \\
\hline 6. & CharadriformesScolopacidae & Tringaochropus & Green Sandpiper & $\mathrm{R}$ \\
\hline 7. & CharadriformesScolopacidae & Tringa tetanus & Common Redshank & $\mathrm{R}$ \\
\hline 8. & CharadriformesScolopacidae & Limosalimosa & Black Tailed Godwit & $\mathrm{R}$ \\
\hline 9. & CharadriformesScolopacidae & Philomachuspugnax & Ruff & $\mathrm{R}$ \\
\hline 10. & CharadriiformesScolopacidae & Tringaglareola & Wood Sandpiper & $\mathrm{R}$ \\
\hline 11. & $\begin{array}{l}\text { Ciconiformes } \\
\text { Ciconidae }\end{array}$ & Anastomusosciatans & $\begin{array}{l}\text { Asian Open Bill } \\
\text { Stork }\end{array}$ & RM \\
\hline 12. & CiconiformesArdeidae & Aredeolagrayii & Indian Pond Heron & $\mathrm{R}$ \\
\hline 13. & CiconiformesArdeidae & Bubulcus ibis & Cattle Egret & $\mathrm{R}$ \\
\hline 14. & CiconiformesArdeidae & Casmerodiusalbus & Large Egret & $\mathrm{RM}$ \\
\hline 15. & CiconiformesArdeidae & Egrettagarzetta & Little Egret & $\mathrm{R}$ \\
\hline 16. & CiconiformesCiconiidae & Mycterialeucocephala & Painted Stork & RM \\
\hline 17. & CiconiformesScolopacidae & Gallinagegallinago & Common Snipe & $\mathrm{R}$ \\
\hline 18. & CiconiformesThreskiornithidae & Pseudibispapillosa & Black Ibis & RM \\
\hline 19. & ColumbiformesColumbidae & Stigmatopeliasenegalensis & Little Brown Dove & $\mathrm{R}$ \\
\hline 20. & ColumbiformesColumbidae & Treronphoenicopterus & $\begin{array}{c}\text { Yellow Footed Green } \\
\text { Pigeon }\end{array}$ & $\mathrm{R}$ \\
\hline 21. & ColumbiformesColumbidae & Columba livia & Rock (Blue) Pigeon & $\mathrm{R}$ \\
\hline 22. & ColumbiformesColumbidae & Streptopeliachinensis & Spotted Dove & $\mathrm{R}$ \\
\hline 23. & CoracifomesAlcedinidae & Cerylerudis & Pied Kingfisher & $\mathrm{R}$ \\
\hline 24. & CoraciformesAlcedinidae & Alcedoatthis & Small Blue Kingfisher & $\mathrm{R}$ \\
\hline 25. & CoraciformesAlcedinidae & Halyconsmyrnesis & $\begin{array}{r}\text { White Breasted } \\
\text { Kingfisher }\end{array}$ & $\mathrm{R}$ \\
\hline 26. & CoraciformesCoraciidae & Coraciasbenghalensis & Indian Roller & $\mathrm{R}$ \\
\hline 27. & CoraciformesMeropidae & Meropsorientalis & Small Green Bee Eater & $\mathrm{R}$ \\
\hline 28. & CoraciformesUpupidae & Upupaepops & Common Hoopoe & $\mathrm{R}$ \\
\hline 29. & CuculiformesCuculidae & Cuculuscanorus & Common Cuckoo & $\mathrm{R}$ \\
\hline 30. & GalliformesGruidae & Amauromisphoenicurus & $\begin{array}{l}\text { White-Breasted Water } \\
\text { Hen }\end{array}$ & $\mathrm{R}$ \\
\hline 31. & GalliformesGruidae & Fulicaatra & Common Coot & RM \\
\hline 32. & GalliformesPhasinidae & Fracolinuspondicerianus & Grey Francolin & $\mathrm{R}$ \\
\hline 33. & PasseridaeCorvidae & DendrocittavagabundaRufous & (Indian) Treepie & $\mathrm{R}$ \\
\hline 34. & Passeriformes Campephagidae & Tephrodornispondicerianus & Common Woodshrike & $\mathrm{R}$ \\
\hline 35. & Passeriformes Corvidae & Corvussplendens & House Crow & $\mathrm{R}$ \\
\hline 36. & Passeriformes Corvidae & Corvusmacrorhynchos & Jungal Crow & $\mathrm{R}$ \\
\hline 37. & Passeriformes Dicrudidae & Dicrurusmacrocercus & Black Drongo & $\mathrm{R}$ \\
\hline 38. & Passeriformes Estrildidae & Amandavaamandava & Red Aavadavat & $\mathrm{R}$ \\
\hline 39. & Passeriformes Hirudinidae & Hirundorustica & Common Swallow & RMC \\
\hline 40. & Passeriformes Lanidae & Laniusschach & Rufousbacked Shrike & $\mathrm{R}$ \\
\hline 41. & Passeriformes Laniidae & Laniusvittatus & Bay Backed Shrike & $\mathrm{R}$ \\
\hline
\end{tabular}




\begin{tabular}{|c|c|c|c|c|}
\hline 42. & Passeriformes Motacillidae & Motacillmaderaspatensis & White Browed Wagtail & $\mathrm{R}$ \\
\hline 43. & Passeriformes Muscicapidae & Turdoidesstriat & Jungal Babbler & $\mathrm{R}$ \\
\hline 44. & Passeriformes Muscicapidae & Saxicolodiesfulicatus & Indian Robin & $\mathrm{R}$ \\
\hline 45. & Passeriformes Muscicapidae & Copsychussaularis & Oriental Magpie Robin & $\mathrm{R}$ \\
\hline 46. & Passeriformes Muscicapidae & Saxicolacaprata & Pied Bushchat & $\mathrm{R}$ \\
\hline 47. & Passeriformes Passeridae & Hydrophasianuschirurgus & $\begin{array}{c}\text { Pheasant Tailed } \\
\text { Jacana }\end{array}$ & $\mathrm{R}$ \\
\hline 48. & Passeriformes Passeridae & Anthusrufulus & Paddyfield Pipit & $\mathrm{R}$ \\
\hline 49. & Passeriformes Pycnonotidae & Pycnonotuscafer & Red Vented Bulbul & $\mathrm{R}$ \\
\hline 50. & Passeriformes Sturnidae & Acridotherestristis & Common Myna & $\mathrm{R}$ \\
\hline 51. & Passeriformes Sturnidae & Sturniapagodarum & Brahminy Starling & $\mathrm{R}$ \\
\hline 52. & Passeriformes Sturnidae & SturnuspagodarumBrahminy & Myna & $\mathrm{R}$ \\
\hline 53. & Passeriformes Sturnidae & Sturnus contra & Pied Myna & $\mathrm{R}$ \\
\hline 54. & Passeriformes Sylvidae & Chrysommasinense & Yellow Eyed Babbler & $\mathrm{R}$ \\
\hline 55. & PelecaniformesPhalcrocoracidae & Phalacrocoraxniger & Little Cormorant & RM \\
\hline 56. & PelecaniformesPhalcrocoracidae & Phalacrocoraxfusicollis & Indian Cormorant & $\mathrm{R}$ \\
\hline 57. & PiciformesPicidae & Dendrocopusmahrattensis & $\begin{array}{l}\text { Yellow-Crowned } \\
\text { Woodpecker }\end{array}$ & $\mathrm{R}$ \\
\hline 58. & PodicipediformesPodicipedidae & Tachybaptusruficollius & Little Grebe & $\mathrm{R}$ \\
\hline 59. & PsittaciformesCuculidae & Eudynamysscolopaceus & Asian Koel & $\mathrm{R}$ \\
\hline 60. & PsittaciformesCuculidae & Centropussinensis & Greater Coucal & $\mathrm{R}$ \\
\hline 61. & PsittaciformesPsittacidae & Psittaculakrameri & Rose Ringed Parakeet & $\mathrm{R}$ \\
\hline 62. & PsittaciformesPsittacidae & Psittaculacyanocephala & Plum Headed Parakeet & $\mathrm{R}$ \\
\hline
\end{tabular}

$\mathrm{R}=$ Resident $\mathrm{M}=$ Migrant

$\mathrm{RM}=$ Resident Migratory RMC $=$ Resident Migrant Common 